\title{
Sistem Pelayanan Dan Monitoring Pengisian LPG Berbasis Mobile Pada PT. XYZ
}

\author{
Yudhi Arta ${ }^{1}$, Apri Siswanto ${ }^{2}$, Adiguna Setiawan ${ }^{3}$ \\ 1,2,3 Program Studi Teknik Informatika, Fakultas Teknik, Universitas Islam Riau \\ Jl. Kaharuddin Nasution No.113 Perhentian Marpoyan, Pekanbaru, Provinsi Riau \\ e-mail: 1yudhiarta@eng.uir.ac.id, ${ }^{2}$ aprisiswanto@eng.uir.ac.id, ${ }^{3}$ bgdun92@gmail.com
}

\begin{abstract}
Abstrak
Agen menjadi mata rantai pendistribusian Liquified Petroleum Gas (LPG) ke toko, warung atau pengecer. Mereka harus mengikuti prosedur sebelum akhirnya diterima menjadi agen. Calon agen harus datang langsung ke Stasiun Pengisian dan Pengangkutan Bulk Elpiji (SPPBE) untuk melengkapi administratif. Setelah verifikasi data, maka petugas akan melakukan survey ke lokasi usaha untuk menilai kelayakan tempat, sarana dan prasarana calon agen baru. Proses monitoring pemesanan gas oleh petugas SPPBE juga dilakukan dengan cara manual.. Sehingga masyarakat bisa mendaftar menjadi agen melalui perangkat mobile yang dimiliki. Proses pemesanan gas di SPPBE juga menjadi lebih mudah karena bisa dilakukan melalui sistem. Sementara itu bagi petugas SPPBE, sistem ini mempermudah proses pencarian lokasi usaha calon agen pada saat akan melakukan survey. Pasalnya sistem dilengkapi dengan fitur Location Based Service (LBS) untuk penandaan titik lokasi calon agen. Selain itu, sistem juga mempermudah petugas dalam proses monitoring pemesanan gas serta mempermudah petugas $S P P B E$ dalam proses validasi pengambilan gas oleh agen.
\end{abstract}

Kata Kunci: Agen, LPG, Monitoring, Pelayanan, Mobile

\begin{abstract}
The agent becomes the chain of distribution of Liquified Petroleum Gas (LPG) to shops, stalls or retailers. They must follow procedures before being accepted as agents. Prospective agents must come directly to the LPG Bulk Filling and Transporting Station (SPPBE) to complete the administration. After verification of the data, the officer will conduct a survey to the business location to assess the feasibility of the place, facilities and infrastructure of the prospective new agent. The process of monitoring gas orders by SPPBE officers is also done manually. . The process of ordering gas in SPPBE also becomes easier because it can be done through the system. Meanwhile for SPPBE officers, this system facilitates the process of searching for business locations of prospective agents when going to survey. The reason is the system is equipped with a Location Based Service $(L B S)$ feature for marking the location points of prospective agents. In addition, the system also facilitates officers in the process of monitoring gas orders and facilitates SPPBE officers in the process of validating the gas collection by agents.
\end{abstract}

Keywords: Agent, LPG, Monitoring, Service, Mobile

\section{Pendahuluan}

Penggunaan gas LPG atau Liquified Petroleum Gas semakin meningkat sejak bergulirnya program konversi minyak tanah ke gas oleh pemerintah [1]. Kondisi ini menjadi peluang usaha untuk menjadi agen gas LPG. Agen menjadi mata rantai distribusi LPG ke toko, warung atau pengecer. Mereka melakukan serangkaian aktvitas untuk mendaftar menjadi agen melalui Stasiun Pengisian dan Pengangkutan Bulk Elpiji (SPPBE). Pada proses pendaftaran, agen harus menyerahkan persyaratan administratif dengan datang langsung ke kantor SPPBE. 
Setelah persyaratan administrasi lengkap, pihak petugas akan melakukan survei untuk melihat lokasi, kelengkapan sarana dan prasarana agen baru tersebut. Petugas sering kali kesulitan menemukan alamat calon agen tersebut. Mereka harus bertanya kepada masyarakat sekitar atau mengikuti petunjuk jalan. Setelah melakukan pengecekkan, beberapa hari kemudian SPPBE akan menyampaikan terkait pengajuan terbuat apakah diterima atau ditolak melalui surat. Proses manual juga dilakukan saat akan melakukan pengisian gas. Pertama, agen melakukan pembayaran ke Bank untuk mendapatkan nomor Sales Order (SO). Kemudian SO diserahkan kepada pihak pertamina untuk mendapatkan Loading Order (LO). LO berfungsi sebagai surat perintah dari Pertamina kepada SPPBE untuk mengisi tabung gas yang dibawa agen. Setelah mendapatkan LO, agen kemudian mendatangi SPPBE untuk melakukan pengisian tabung. Sesampainya di SPPBE, petugas di sana akan melakukan pengecekan jumlah tabung dan Safety Car armada Agen. Jika sesuai dengan jumlah SO dan LO, serta memenuhi persyaratan Safety Car, maka armada Agen diperbolehkan masuk ke area Filling Hall, dan melakukan pengisian Bulk LPG. Kemudian, armada Agen diperbolehkan keluar dari area SPPBE dengan memperlihatkan bukti SPP kepada petugas.

\section{Metode Penelitian}

Pada penelitian ini, penulis menggunakan metode penelitian jenis penelitian eksperimen, dengan tahapan penelitian seperti berikut : [2][3][4]

1. Pengumpulan Data

2. Persiapan Alat dan Bahan Penelitian

3. Analisis dan Perancangan Sistem

4. Pembuatan Sistem

5. Implementasi atau Uji Coba Sistem

\subsection{Pengumpulan Data}

Adapun teknik pengumpulan data yang dilakukan oleh penulis adalah sebagai berikut :

1. Observasi, yaitu pengumpulan data yang dilakukan dengan cara langsung ke lapangan.

2. Wawancara, yaitu teknik pengumpulan data dengan sesi tanya jawab dilakukan untuk mendapatkan data dan keterangan secara langsung.

3. Studi kepustakaan, yaitu melakukan penelitian di perpustakaan dengan cara mencari buku dan literatur yang berhubungan dengan penelitian.

\subsection{Aplikasi Mobile}

Aplikasi Mobile adalah sebuah aplikasi yang memungkinkan anda melakukan mobilitas dengan menggunakan perlengkapan seperti Personal Digital Assistant (PDA), telepon seluler atau Handphone. Dengan menggunakan aplikasi mobile, anda dapat dengan mudah melakukan berbagai macam aktifitas mulai dari hiburan, berjualan, belajar, mengerjakan pekerjaan kantor, browsing dan lain sebagainya. [5][6][7]

\section{Hasil Dan Pembahasan}

Perancangan Sistem

Sistem yang akan penulis bangun ini mempermudah agen dalam proses pendaftaran dan pengisian gas LPG, serta sistem yang dapat mempermudah pihak SPPBE dalam proses monitoring pendaftaran agen dan pemesanan gas. Untuk proses pendaftaran, agen hanya perlu masuk ke dalam sistem dan mengunggah persyaratan yang sudah ditetapkan.

Kemudian, admin SPPBE akan melakukan verifikasi data. Jika persyaratan lengkap, maka sistem akan mengirimkan SMS Gateway kepada calon agen baru yang berisi terkait waktu survei. Sistem ini juga dilengkapi dengan fitur Location Based Services (LBS), sehingga bisa langsung menandai titik agen baru tersebut. Dengan demikian, petugas survei akan lebih mudah 
dalam mencari lokasi calon agen. Sistem kemudian akan mengirimkan SMS Gateway terkait hasil survei. Jika diterima, maka sistem akan menginformasikan waktu pengambilan surat izin.

Pada proses pemesanan gas, agen bisa memesan melalui sistem. Admin SPPBE kemudian melakukan validasi.

Jika permintaan pemesanan diterima, agen akan menerima SMS Gateway berisi jumlah uang yang harus dibayarkan. Agen yang sudah melakukan pembayaran harus melakukan konfirmasi ke dalam sistem. Kemudian pihak SPPBE akan melakukan validasi dan menginformasikan jika pembayaran sudah diterima melalui SMS Gateway. Selanjutnya, sistem akan menampilkan kode QR yang berfungsi sebagai bukti yang ditunjukan kepada petugas saat agen melakukan pengambilan gas di SPPBE. Selain agen, sistem ini juga dibangun untuk mempermudah SPPBE dalam proses monitoring pendaftaran agen dan pemesanan gas.

\section{Context Diagram}

Context Diagram digunakan untuk menggambarkan hubungan input dan output antara sistem dengan entitas luar, [8][9] suatu diagram konteks selalu memiliki satu proses yang mewakili seluruh system dan dapat dilihat seperti gambar 1 .

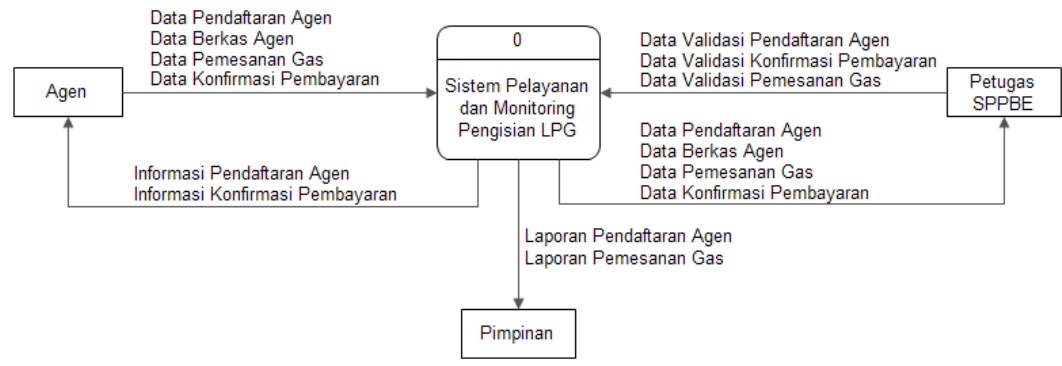

Gambar 1. Konteks Diagram

\section{Hirarchy Chart}

Adapun pada gambar 2 dibawah merupakan tahapan dari hierarchy chart sebagai berikut :

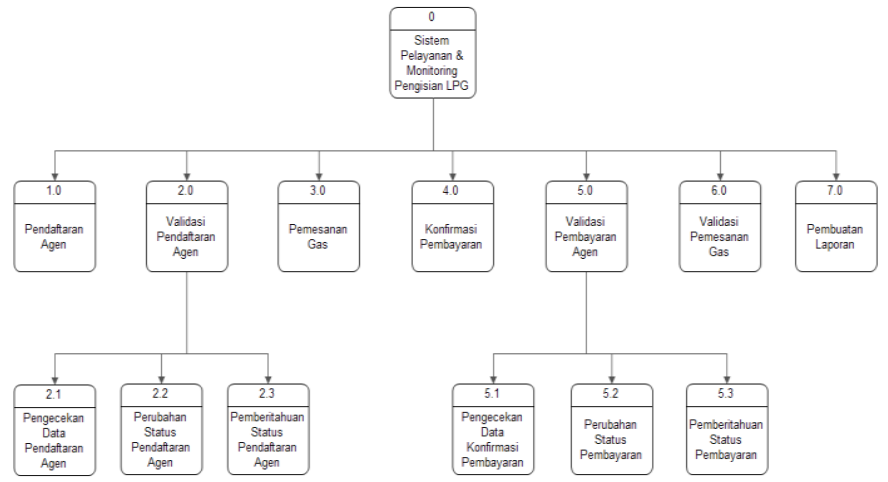

Gambar 2. Hirarchy Chart

3. Data Flow Diagram (DFD) Level 0

DFD level 0 merupakan representasi dari data context diagram[10]. Pada sistem ini terdapat 7 proses yaitu proses pendaftaran agen, validasi pendaftaran agen, pemesanan gas, konfirmasi pembayaran, validasi pembayaran agen, validasi pemesanan gas dan pembuatan laporan. Berikut gambaran DFD level 0 pada sistem ini. 


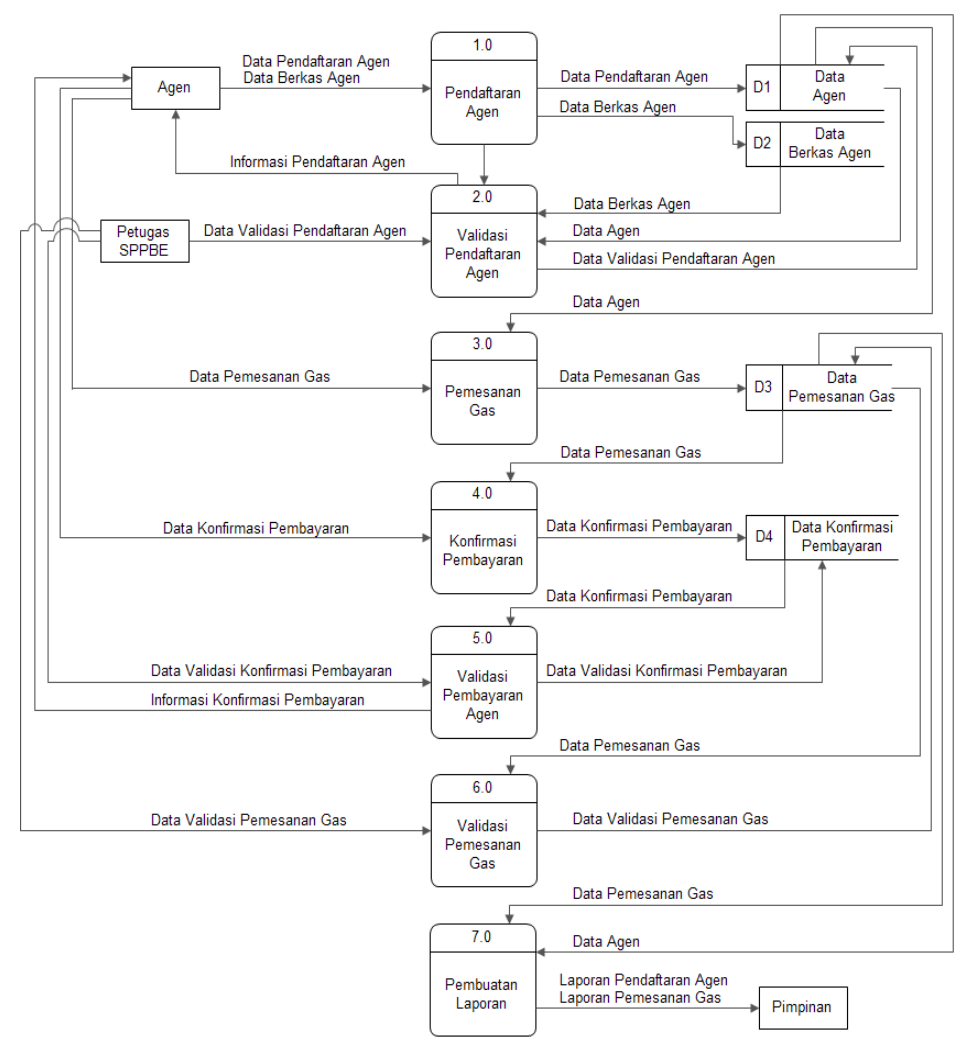

Gambar 3. Data Flow Diagram level 0

4. Entity Relationship Diagram (ERD)

ERDmerupakan gambaran relasi dalam basis data. Berikut rancangan ERD dalam sistem ini dapat dilihat pada gambar 5 .

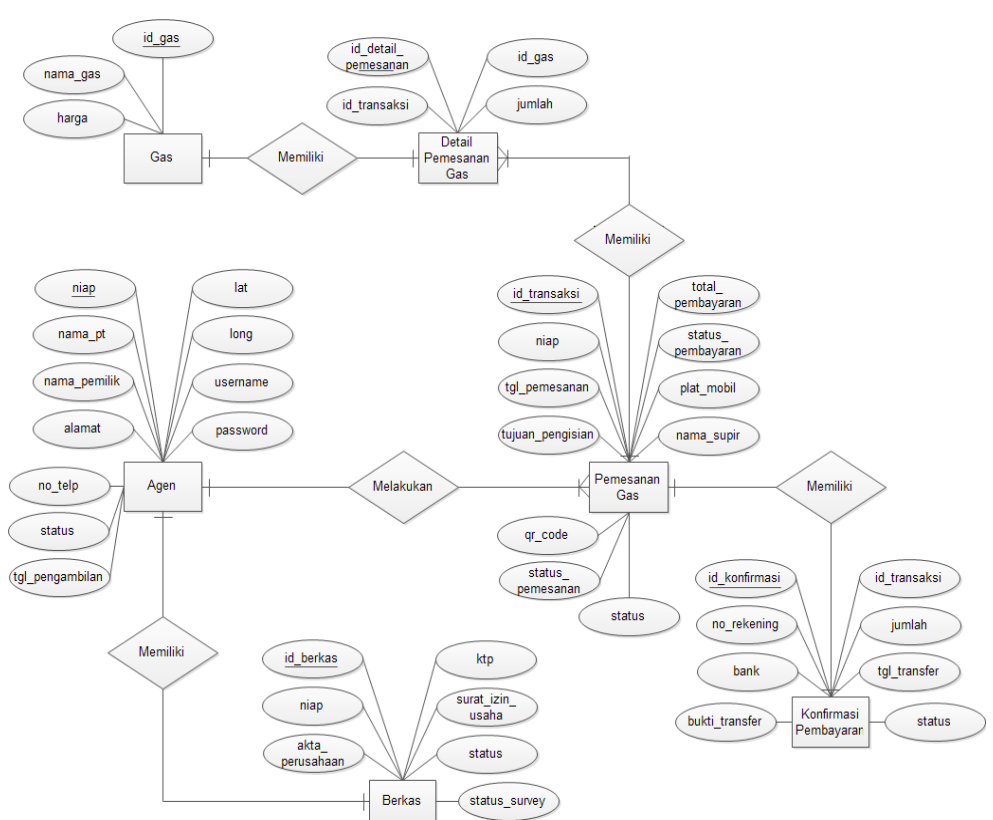

Gambar 4. Entity Relationship Diagram 


\section{Pengujian Sistem}

Petugas SPPBE harus login ke dalam sistem untuk dapat melakukan pengolahan data pada sistem. Petugas SPPBE hanya tinggal memasukkan username dan password yang telah terdaftar di sistem. Berikut ini tampilan halaman login petugas SPPBE tersebut.

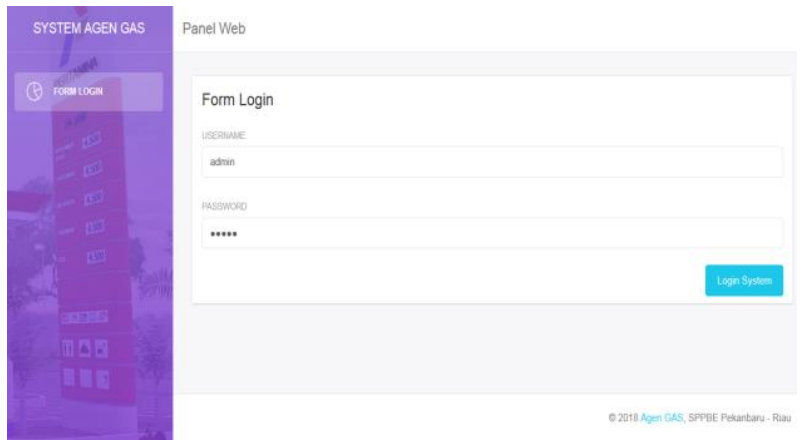

Gambar 5. Pengujian Form Login Admin Tampilan Web Based

6. Halaman Menu Utama Admin

Setelah petugas SPPBE memasukkan username dan password dengan benar, sistem akan mengarahkan petugas SPPBE pada menu utama sistem. Berikut ini tampilan menu utama petugas SPPBE tersebut.

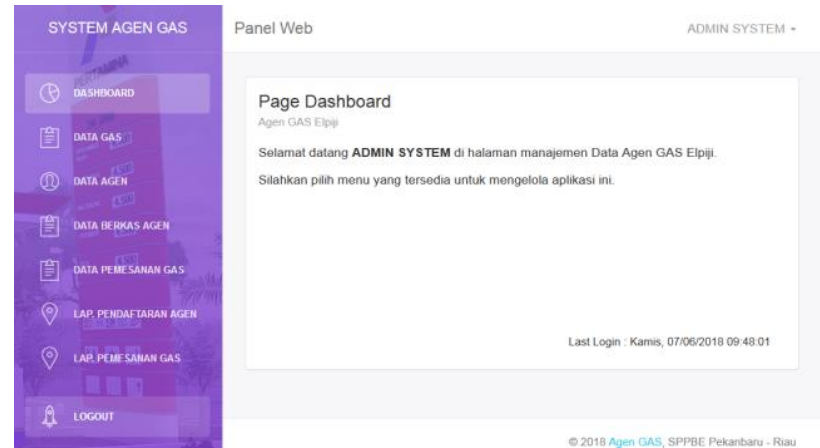

Gambar 6. Menu Utama Admin Setelah LoginTampilan Web Bases

7. Pengujian Tambah Data Gas

Pada halaman tambah data gas, petugas SPPBE harus mengisi form penambahan data gas ini dengan lengkap dan benar. Data gas ini meliputi nama gas dan harga. Berikut ini halaman tambah data gas tersebut.

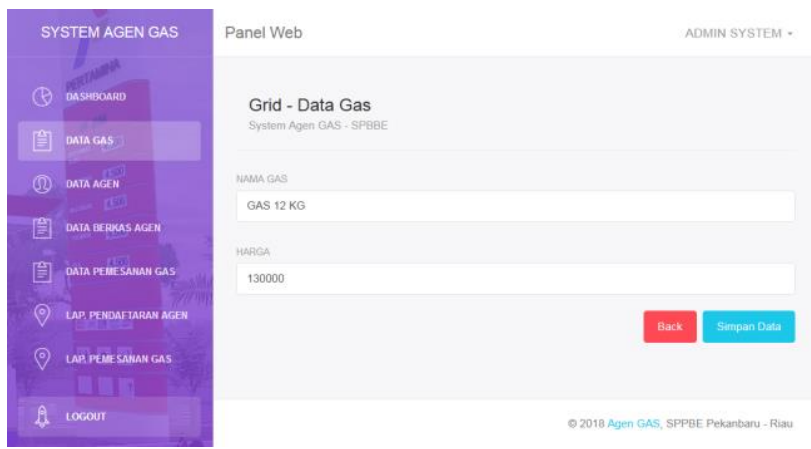

Gambar 7. Pengujian Tambah Data Gas 


\section{Pengujian Pendaftaran Data Agen Gas}

Pada halaman tambah data agen gas ini, calon agen gas harus mengisi form penambahan data agen gas ini dengan lengkap dan benar. Data agen gas ini meliputi nama nama perusahaan, nama pemilik, alamat, nomor telpon, lokasi, username dan password. Berikut ini halaman tambah data agen gas tersebut.

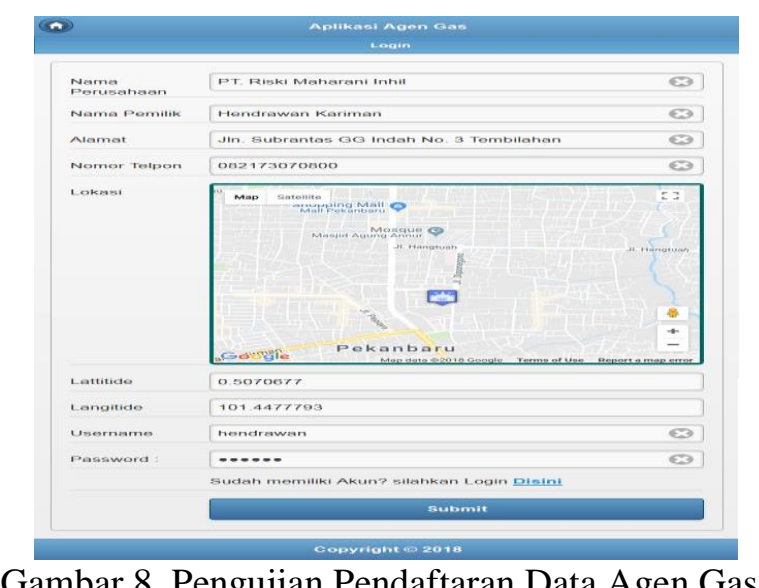

9. Pengujian Login Pengguna Sistem Mobile

Petugas SPPBE atau agen gas harus login ke dalam sistem untuk dapat melakukan pengolahan data pada sistem. Petugas SPPBE atau agen gas hanya tinggal memasukkan username dan password yang telah terdaftar di sistem. Berikut ini tampilan halaman login pengguna system mobile tersebut.

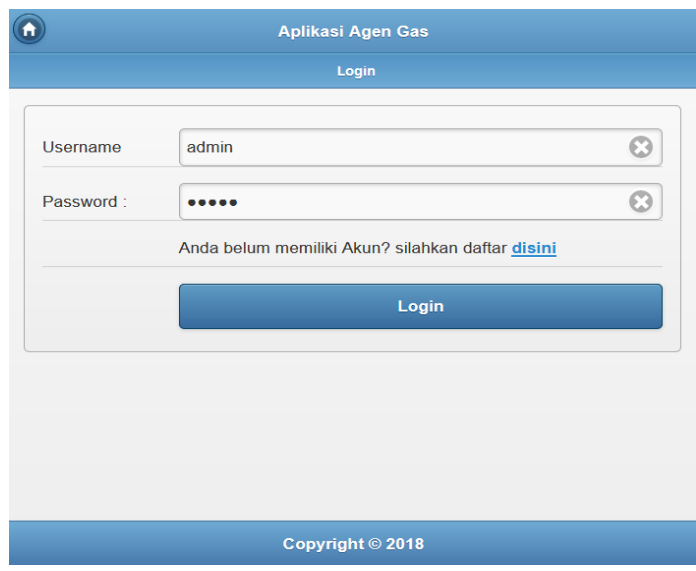

Gambar 9. Pengujian Login Petugas SPPBE Dan Agen (Mobile)

Setelah petugas SPPBE dan agen gas memasukkan username dan password dengan benar, sistem akan mengarahkan petugas SPPBE dan agen gas pada menu utama sistem sesuai dengan level pengguna pada sistem.

\section{Pengujian Tambah Data Pemesanan Gas}

Pada halaman tambah data pemesanan gas ini, agen gas harus mengisi form penambahan data pemesanan gas ini dengan lengkap dan benar. Data pemesanan gas ini meliputi tujuan pengisian, material, dan jumlah. Berikut ini halaman tambah data pemesanan gas tersebut. 


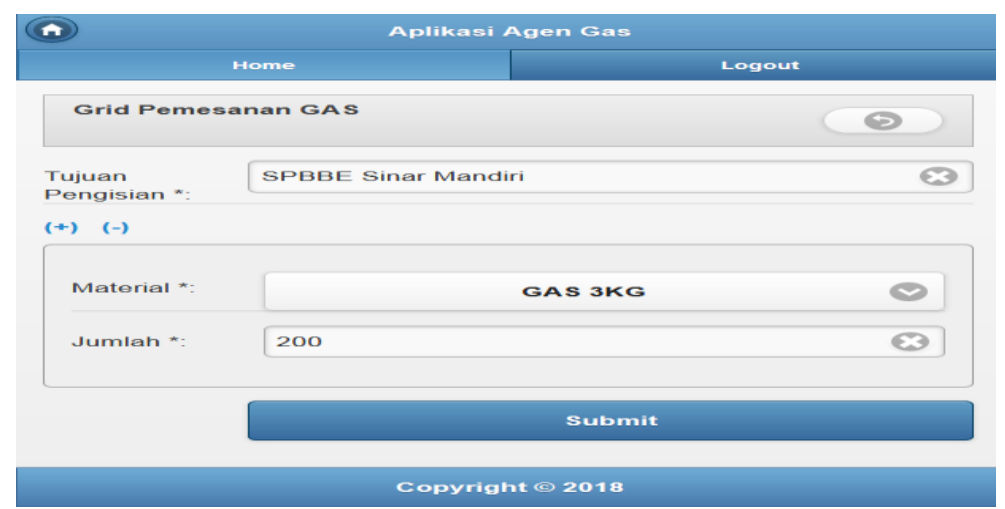

Gambar 10. Pengujian Tambah Data Pemesanan Gas

\section{Pengujian Validasi Data Pemesanan Gas}

Pada halaman validasi data pemesanan gas ini, petugas SPPBE hanya tinggal merubah status dari pemesanan gas tersebut. Berikut ini tampilan halaman validasi data pemesanan gas tersebut.

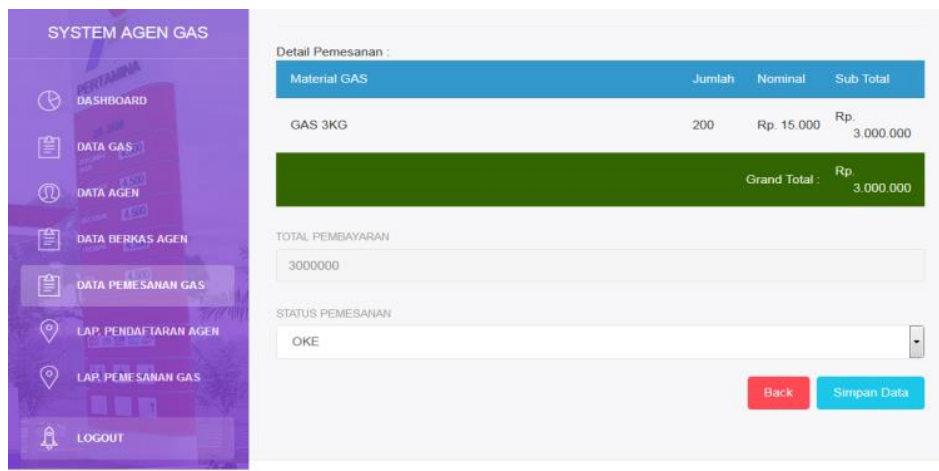

Gambar 11. Pengujian Validasi Data Pemesanan Gas

12. Pengujian Tambah Data Konfirmasi Pembayaran

Pada halaman tambah data konfirmasi pembayaran ini, agen gas harus mengisi form penambahan data konfirmasi pembayaran ini dengan lengkap dan benar. Data konfirmasi pembayaran ini meliputi tanggal transfer, bank, nomor rekening, jumlah, dan bukti transfer. Berikut ini halaman tambah data konfirmasi pembayaran tersebut.

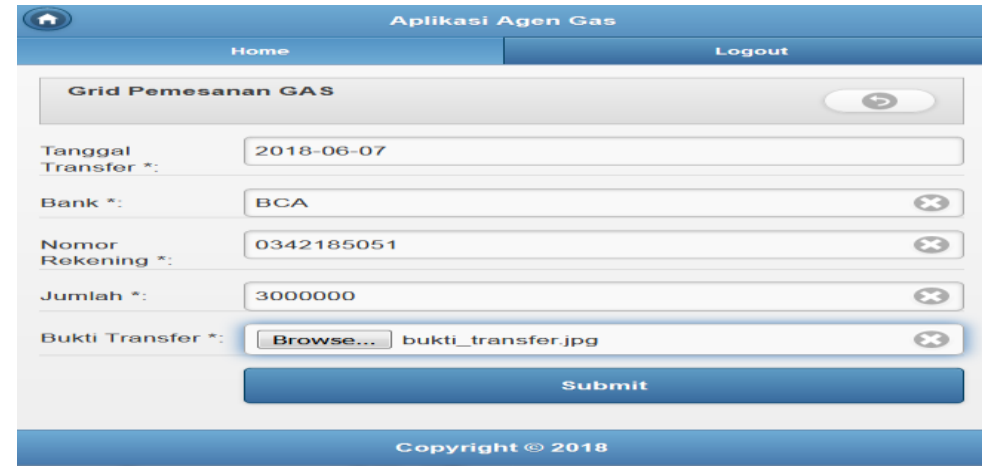

Gambar 12. Pengujuan Tambah Data Konfirmasi Pembayaran 


\section{Pengujian Validasi Data Pembayaran}

Pada halaman validasi data pembayaran ini, petugas SPPBE hanya tinggal merubah status dari pembayaran tersebut. Berikut ini tampilan halaman validasi data pembayaran tersebut.
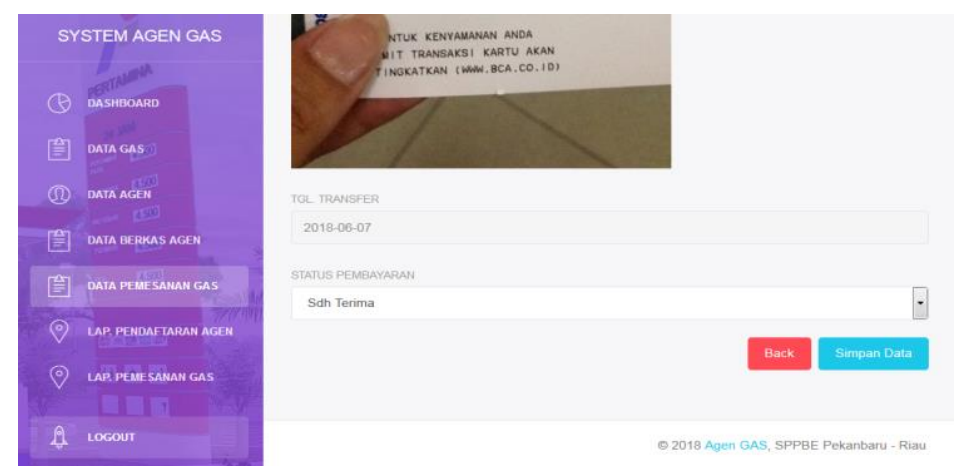

Gambar 13. Pengujian Validasi Data Pembayaran

\section{Pengujian Cetak Laporan Pendaftaran Agen}

Pada halaman cetak laporan pendaftaran agen ini, petugas SPPBE hanya tinggal memasukkan tanggal awal dan tanggal akhir dari laporan yang ini dicetak dari laporan ini. Berikut ini form cetak laporan pendaftaran agen tersebut

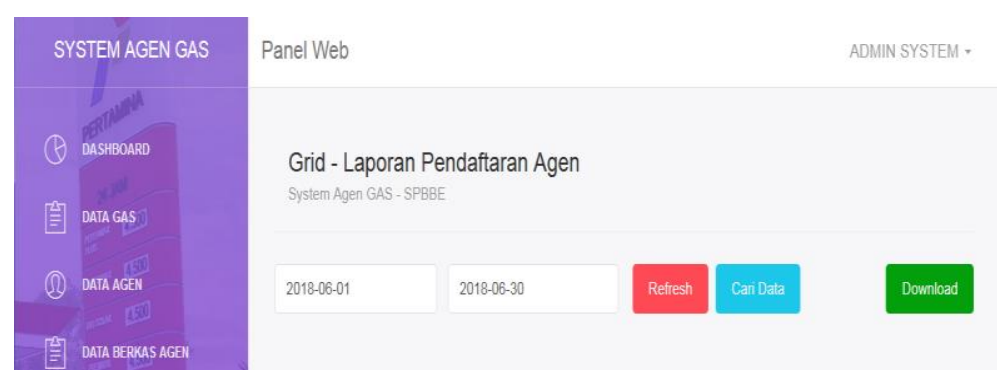

Gambar 14. Pengujian Cetak Laporan Pendaftaran Agen

\begin{tabular}{|c|c|c|c|c|c|c|}
\hline \multicolumn{7}{|c|}{$\begin{array}{l}\text { LAPORAN DATA PENDAFTARAN AGEN } \\
\text { SPBBE PEKANBARU - RIAU }\end{array}$} \\
\hline No & NIAP & PEMIIIK & PERUSAHAAN & ALAMAT & NO. TELPON & TGL. INPUT \\
\hline 1. & 112411371 & SURYA WDADA & PT. Indah Gas Lestari & ת. mawar puthih no 221 & 085376341110 & 04:06:2018 22:34:54 \\
\hline 2. & 112736949 & AMIN SAUJANA & PT. Sinaradia Tritama & $\begin{array}{l}\text { I1. M. Yamin SH. Ruko } \\
\text { No. } 3 \text { Bangkinang }\end{array}$ & 081267232051 & 06:06:2018 11:51:03 \\
\hline 3. & 112947661 & GUNAWAN WINAHYU & PT. Sinaradia Tritama & $\begin{array}{l}\text { I. M. Yamin SH. Ruko } \\
\text { No.3 Bangkinang } \\
\end{array}$ & 081267232051 & 06:06/2018 12:05:55 \\
\hline 4. & 112394664 & FRIDA WAHYU & PT. Raih Usaha Karya Mandiri & \begin{tabular}{|l|} 
ת. Durian No. 10 \\
Pekanbaru
\end{tabular} & 081267232051 & 06:06/2018 12:29:36 \\
\hline 5. & 112640725 & HANGGRA PUTRA & PT Tirta Buana Perkasa & ת. Perdagangan No. 210 & 081267232051 & 06/06/2018 12:40:03 \\
\hline 6. & 112395872 & SUNDANG SONATA & PT. Samudra Mandiri Dumai & \begin{tabular}{|l|} 
ת. Senapelan No. 47 \\
\end{tabular} & 081267232051 & 06:06/2018 12:52:10 \\
\hline 7. & 112745923 & JONSON & PT. Cahaya Kerinci Abadi & \begin{tabular}{|l} 
Sn Peemda No.5.5 \\
Panpkelan Kerinci - \\
Pelelawan
\end{tabular} & 081267232051 & 06:06:2018 12:58:02 \\
\hline 8. & 112513900 & HENDRAWAN KARIMAN & PT. Riski Maharani Inhil & $\begin{array}{l}\text { Inn. Subrantas GG Indah } \\
\text { No. } 3 \text { Tembilahan }\end{array}$ & 082173070800 & 0706:2018 10:11:09 \\
\hline
\end{tabular}

Gambar 15. Hasil Cetak Laporan Pendaftaran Agen

\section{Pengujian Cetak Laporan Pemesanan Gas}

Pada halaman cetak laporan pemesanan gas ini, petugas SPPBE hanya tinggal memasukkan tanggal awal dan tanggal akhir dari laporan yang ini dicetak dari laporan ini. Berikut ini form cetak laporan pemesanan gas tersebut. 


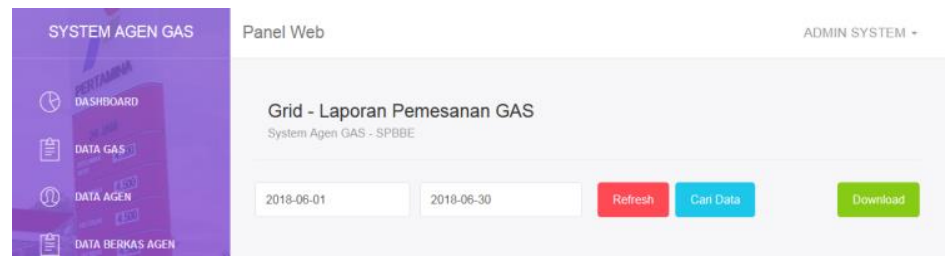

Gambar 16. Pengujian Cetak Laporan Pemesanan Gas

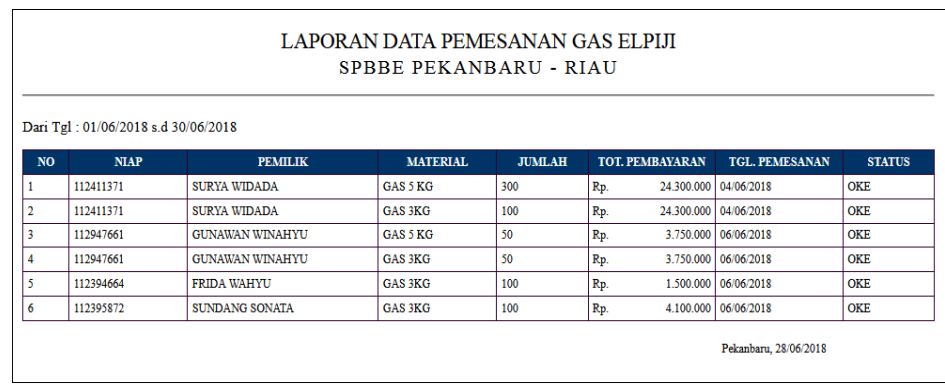

Gambar 17. Hasil Cetak Laporan Pemesanan Gas

\section{Pengujian Menggunakan User Acceptance Test}

User acceptance test merupakan tahap selanjutnya dalam pengujian yang digunakan dalam penelitian ini. Penulis membuat kuisioner dan menyebarkannya kepada petugas SPPBE dan agen gas yang akan menggunakan sistem. Berikut ini detail pengujian user acceptance test terhadap sistem ini.

\section{Implementasi Sistem}

Implementasi sistem yang dipakai adalah membuat kuisoner dengan 9 pertanyaan dan jumlah koresponden berjumlah 30 koresponden yang terdiri dari 20 agen gas, dan 10 orang petugas SPPBE. Kepada koresponden diajukan pertanyaan yang terkait dengan kinerja dari sistem. Berikut ini kuisoner untuk agen gas tersebut :

1. Tampilan sistem ini sudah menarik.

2. Sistem ini mudah digunakan.

3. Sistem ini mempermudah masyarakat untuk mendaftar menjadi agen gas LPG.

4. Sistem ini mempermudah agen dalam proses pemesanan gas LPG.

Selain agen gas, kuisoner juga disebarkan kepada petugas SPPBE. Berikut ini kuisoner untuk petugas SPPBE tersebut :

1. Tampilan sistem ini sudah menarik.

2. Sistem ini mudah digunakan.

3. Sistem ini mempermudah petugas SPPBE dalam mencari lokasi untuk melakukan survei calon agen.

4. Sistem ini mempermudah petugas SPPBE dalam proses monitoring pemesanan gas oleh para agen.

5. Sistem ini mempermudah petugas SPPBE dalam proses validasi pengambilan gas LPG Berdasarkan pertanyaan diatas, maka hasil jawaban dari koresponden terhadap kinerja dari sistem berdasarkan pertanyaan yang diajukan adalah sebagai berikut : 


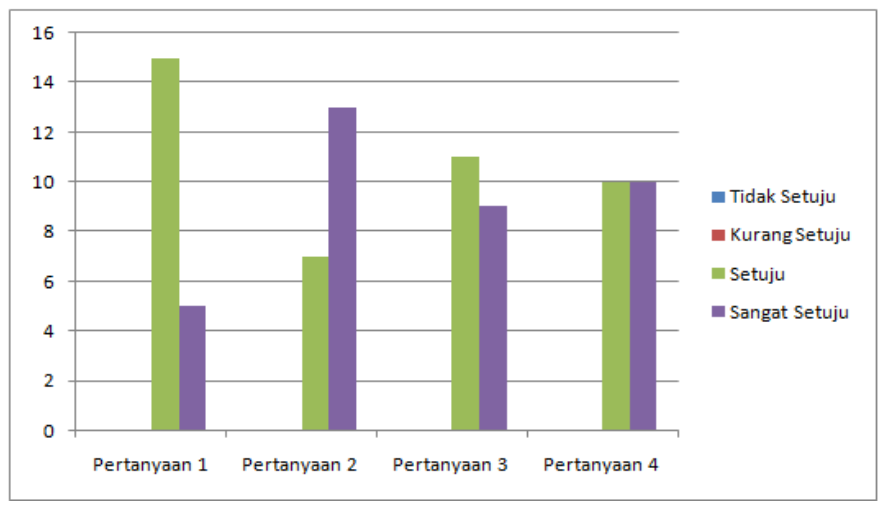

Gambar 18. Grafik Hasil Kuisoner Agen Gas

Keterangan :

1. Tampilan sistem ini sudah menarik memiliki nilai Tidak Setuju: 0 koresponden, Kurang Setuju: 0 Koresponden, Setuju: 15 Koresponden, Sangat Setuju: 5 Koresponden.

2. Sistem ini mudah digunakan memiliki nilai Tidak Setuju: 0 koresponden, Kurang Setuju: 0 Koresponden, Setuju: 7 Koresponden, Sangat Setuju: 13 Koresponden.

3. Sistem ini mempermudah masyarakat untuk mendaftar menjadi agen gas LPG memiliki nilai Tidak Setuju: 0 koresponden, Kurang Setuju: 0 Koresponden, Setuju: 11 Koresponden, Sangat Setuju: 9 Koresponden.

4. Sistem ini mempermudah agen dalam proses pemesanan gas LPG memiliki nilai Tidak Setuju: 0 koresponden, Kurang Setuju: 1 Koresponden, Setuju : 10 Koresponden, Sangat Setuju: 10 Koresponden.

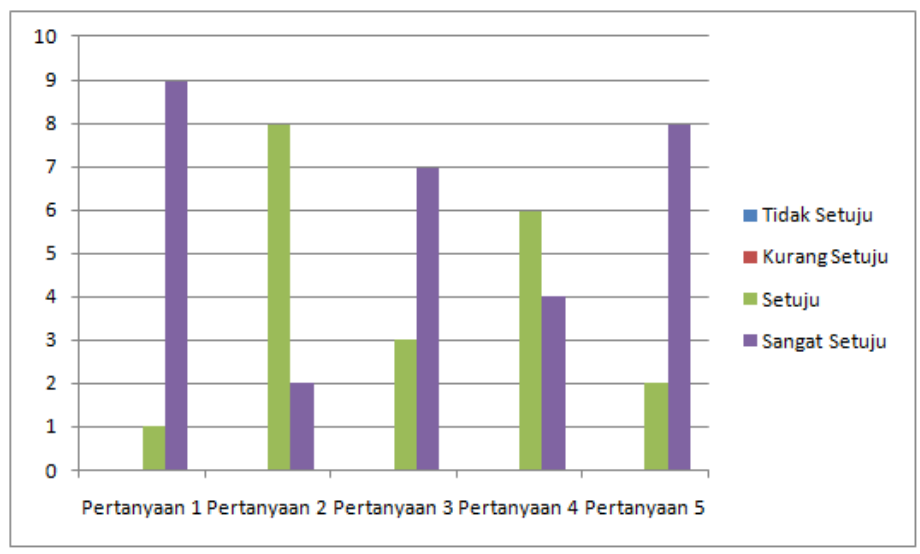

Gambar 19. Grafik Hasil Kuisoner Petugas SPPBE

Keterangan :

1. Tampilan sistem ini sudah menarik memiliki nilai Tidak Setuju: 0 koresponden, Kurang Setuju: 0 Koresponden, Setuju: 1 Koresponden, Sangat Setuju: 9 Koresponden.

2. Sistem ini mudah digunakan memiliki nilai Tidak Setuju: 0 koresponden, Kurang Setuju: 0 Koresponden, Setuju: 8 Koresponden, Sangat Setuju: 2 Koresponden.

3. Sistem ini mempermudah petugas SPPBE dalam mencari lokasi untuk melakukan survei calon agen memiliki nilai Tidak Setuju: 0 koresponden, Kurang Setuju: 0 Koresponden, Setuju : 3 Koresponden, Sangat Setuju: 7 Koresponden. 
4. Sistem ini mempermudah petugas SPPBE dalam proses monitoring pemesanan gas oleh para agen memiliki nilai Tidak Setuju: 0 koresponden, Kurang Setuju: 0 Koresponden, Setuju : 6 Koresponden, Sangat Setuju: 4 Koresponden.

5. Sistem ini mempermudah petugas SPPBE dalam proses validasi pengambilan gas LPG memiliki nilai Tidak Setuju: 0 koresponden, Kurang Setuju: 0 Koresponden, Setuju : 2 Koresponden, Sangat Setuju: 8 Koresponden.

\section{Implementasi Sistem}

Berdasarkan hasil kuisoner, maka dapat disimpulkan bahwa ini memiliki persentase sebagai berikut:

Tabel 1. Hasil Nilai Pertanyaan Kuisioner Agen Gas

\begin{tabular}{clcccc}
\hline No & \multicolumn{1}{c}{ Pertanyaan } & $\begin{array}{c}\text { Tidak } \\
\text { Setuju }\end{array}$ & $\begin{array}{c}\text { Kurang } \\
\text { Setuju }\end{array}$ & Setuju & $\begin{array}{c}\text { Sangat } \\
\text { Setuju }\end{array}$ \\
\hline 1 & $\begin{array}{l}\text { Rancangan sistem ini mudah } \\
\text { digunakan. }\end{array}$ & 0 & 0 & 15 & 5 \\
\hline 2 & $\begin{array}{l}\text { Tampilan sistem ini sudah } \\
\text { menarik. }\end{array}$ & 0 & 0 & 7 & 13 \\
\hline 3 & $\begin{array}{l}\text { Sistem ini mempermudah } \\
\text { masyarakat untuk mendaftar } \\
\text { menjadi agen gas LPG. }\end{array}$ & 0 & 0 & 11 & 9 \\
\hline 4 & $\begin{array}{l}\text { Sistem ini mempermudah } \\
\text { agen dalam proses pemesanan } \\
\text { gas LPG. }\end{array}$ & 0 & 0 & 10 & 10 \\
\hline & Total & $\mathbf{0}$ & $\mathbf{0}$ & $\mathbf{4 3}$ & $\mathbf{3 7}$ \\
\hline
\end{tabular}

Tabel 2. Hasil Nilai Pertanyaan Kuisoner Petugas SPPBE

\begin{tabular}{clcccc}
\hline No & \multicolumn{1}{c}{ Pertanyaan } & $\begin{array}{c}\text { Tidak } \\
\text { Setuju }\end{array}$ & $\begin{array}{c}\text { Kurang } \\
\text { Setuju }\end{array}$ & Setuju & $\begin{array}{c}\text { Sangat } \\
\text { Setuju }\end{array}$ \\
\hline 1 & $\begin{array}{l}\text { Tampilan sistem ini sudah } \\
\text { menarik.. }\end{array}$ & 0 & 0 & 1 & 9 \\
\hline 2 & Sistem ini mudah digunakan. & 0 & 0 & 8 & 2 \\
\hline 3 & $\begin{array}{l}\text { Sistem ini mempermudah } \\
\text { petugas SPPBE dalam mencari } \\
\text { lokasi untuk melakukan survei } \\
\text { calon agen. }\end{array}$ & 0 & 2 & 3 & 7 \\
\hline 4 & $\begin{array}{l}\text { Sistem ini mempermudah } \\
\text { petugas SPPBE dalam proses } \\
\text { monitoring pemesanan gas } \\
\text { oleh para agen. }\end{array}$ & 0 & 0 & 6 & 4 \\
\hline 5 & $\begin{array}{l}\text { Sistem ini mempermudah } \\
\text { petugas SPPBE dalam proses } \\
\text { validasi pengambilan gas LPG. }\end{array}$ & 0 & 0 & 2 & 8 \\
\hline Total & $\mathbf{0}$ & $\mathbf{0}$ & $\mathbf{2 0}$ & $\mathbf{3 0}$ \\
\hline
\end{tabular}

Maka secara keseluruhan penilaian kualitas aspek sistem ini dapat dihitung dengan menggunakan rumus tabulasi. Berdasarkan rumus ini, masing-masing kondisi diperoleh persentase sebagai berikut: 
1. $\mathrm{P}_{\text {tidak setuju }}=(0 / 80) * 25=0 \%$

2. $\mathrm{P}_{\text {kurang setuju }=}(0 / 80) * 50=0 \%$

3. $\mathrm{P}_{\text {setuju }}=(43 / 80) * 75=40.31 \%$

4. $\mathrm{P}_{\text {sangat setuju }}=(37 / 80) * 100=46.25 \%$

Maka total presentase didapat dengan menjumlahkan $\mathrm{P}_{\text {tidak setuju }}+\mathrm{P}_{\text {kurang setuju }}+\mathrm{P}_{\text {setuju }}+\mathrm{P}_{\text {sangat }}$ setuju, sehingga didapat nilai aspek penggunaan sistem pada kuisoner agen gas ini sebesar $86.56 \%$ atau diinterpretasikan sangat setuju. Sementara itu hasil penilaian kualitas aspek sistem untuk kuisoner petugas SPPBE diperoleh persentase sebagai berikut :

1. $\mathrm{P}_{\text {tidak setuju }}=(0 / 50) * 25=0 \%$

2. $\mathrm{P}_{\text {kurang setuju }=}(0 / 50) * 50=1.50 \%$

3. $\mathrm{P}_{\text {setuju }}=(20 / 50) * 75=30.00 \%$

4. $\mathrm{P}_{\text {sangat setuju }}=(30 / 50) * 100=60.00 \%$

Maka total presentase didapat dengan menjumlahkan $\mathrm{P}_{\text {tidak setuju }}+\mathrm{P}_{\text {kurang setuju }}+\mathrm{P}_{\text {setuju }}+\mathrm{P}_{\text {sangat }}$ setuju , sehingga didapat nilai aspek penggunaan sistem pada kuisoner petugas SPPBE ini sebesar $90.00 \%$ atau diinterpretasikan sangat setuju. Dari hasil persentasi kedua kuisoner ini yakni $86.56 \%$ dan $90.00 \%$ maka diambil nilai rata-rata dari kedua hasil persentase tersebut, sehingga didapat nilai persentase sebesar $88.28 \%$ diinterpretasikan sangat setuju.

\section{Kesimpulan}

Berdasarkan hasil analisa dan pembahasan yang telah dilakukan melalui sistem yang telah dibuat, dapat diambil kesimpulan sebagai berikut:

1. Sistem ini mempermudah masyarakat untuk mendaftar menjadi agen gas LPG.

2. Sistem ini mempermudah agen dalam proses pemesanan gas LPG.

3. Sistem ini mempermudah petugas SPPBE dalam mencari lokasi usaha calon agen.

4. Sistem ini mempermudah petugas SPPBE dalam proses validasi pengambilan gas LPG.

5. Sistem ini mempermudah agen dalam proses pemesanan gas LPG.

6. Sistem ini mempermudah masyarakat untuk mendaftar menjadi agen gas LPG.

7. Dari hasil kusioner yang telah disebarkan, menunjukan bahwa total persentase nilai aspek pengunaan sistem ini sebesar $88.28 \%$ atau diinterpretasikan sangat setuju.

\section{Daftar Pustaka}

[1] Pranadji, D. K., Djamaludin, M. D., \& Kiftiah, N. (2010). Analisis Perilaku Penggunaan LPG Pada Rumah Tangga di Kota Bogor. Jurnal Ilmu Keluarga \& Konsumen, 3(2), 172183.

[2] Jogiyanto, H.M., 2005, Analisa \& Desain Sistem Informasi, Andi Offset, Yogyakarta

[3] Kadir, Abdul., 2009, Pengenalan Sistem Informasi, Andi Offset, Yogyakarta

[4] Kadir, Ab dul., 2009, Pengenalan Sistem Informasi, Andi Offset, Yogyakarta 
[5] B. R. Rompas, 2012, Aplikasi Location-Based Service Pencarian Tempat Di Kota Manado Berbasis Android, Skripsi, Universitas Sam Ratulangi Manado.

[6] Tim E-Media Solusindo., 2013, Android All In One, PT Elex Media Komputindo, Jakarta

[7] Andi, 2009, Global Positioning System, Andi, Yogyakarta

[8] Syafitri, Nesi, \& Alfred Apdian. " Sistem Pakar untuk Mendiagnosa Obesitas pada Anak dengan Menggunakan Metode Backward Chaining." IT JOURNAL RESEARCH AND DEVELOPMENT [Online], 1.1 (2016): 1 - 8. Web. 30 Oct. 2018

[9] Setiawan, Panji. " Arsitektur Informasi Untuk Electronic Bidding." IT JOURNAL RESEARCH AND DEVEL OPMENT [Online], 2.1 (2017): 19 - 31. Web. 30 Oct. 2018

[10] Syukur, Abdul, \& Dian Suprayogi. " Game Tradisional Tarik Tambang Berbasis Web." IT JOURNAL RESEARCH AND DEVELOPMENT [Online], 1.1 (2016): 38 - 49. Web. 30 Oct. 2018 